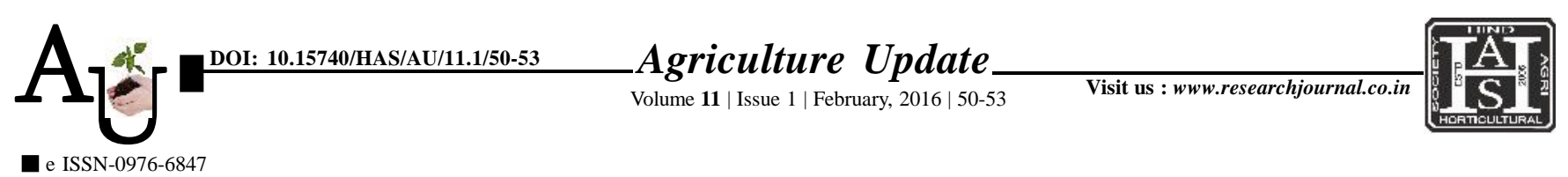

\title{
Research Article: Job satisfaction of teachers in horticulture college, Arabhavi
}

Article Chronicle: Received :

13.11.2014;

Revised :

04.01.2016;

Accepted :

18.01.2016

KEY WoRDS :

Job satisfaction,

Teachers, Mean

score, Standard

deviation
Author for correspondence :

\section{SHREESHAIL}

\section{RUDRAPUR}

Department of Agricultural Economics, College of Agriculture, University of Agricultural Sciences, DHARWAD (KARNATAKA) INDIA Email: shree4476@ gmail.com

See end of the article for authors' affiliations

\section{SHREESHAIL RUDRAPUR, ANIL BIRADAR, MITHUN P. KUDACHI AND SANTOSH BALIKAI}

SUMMARY : The study conducted revealed that majority of the teachers were satisfied with the salary as the present salary is in commensurate with the work and position (52.00\%) and salary paid is a vital source of satisfaction $(60.00 \%)$. In case of job security also majority of the teachers were satisfied as the performance will be assessed objectively before taking any serious actions $(68.00 \%)$ and guidance will be given to improve the job $(64.00 \%)$. The teachers were highly satisfied with teaching the students $(60.00 \%)$. Majority of the teachers were satisfied with working conditions with respect to distance from office to home (36.00\%), provision of separate chair, table and almera in office (32.00), provision of quarters $(36.00 \%)$, provision of transportation $(36.00 \%)$, job authority delegated to me in the present job $(72.00 \%)$ and opportunity to work with team spirit $(68.00 \%)$. The data also revealed that majority of them belonged to high and medium job satisfaction category ( $28 \%$ high and $36 \%$ medium). And among the remaining $36 \%$ of them belonged to the low job satisfaction category. The mean job satisfaction score of all the teachers was 97.40 with a standard deviation of 9.93 .

How to cite this article : Rudrapur, Shreeshail, Biradar, Anil, Kudachi, Mithun P. and Balikai, Santosh (2016). Job satisfaction of teachers in horticulture college, Arabhavi. Agric. Update, 11(1): 50-53. 